December 2005

IMF Country Report No. 05/423

\title{
Norway: Report on the Observance of Standards and Codes- FATF Recommendations for Anti-Money Laundering and Combating the Financing of Terrorism
}

This Report on the Observance of Standards and Codes on the FATF Recommendations for Anti-Money Laundering and Combating the Financing of Terrorism for Norway was prepared by the Financial Action Task Force on Money Laundering (FATF), using the assessment methodology adopted by the Financial Action Task Force in February 2004 and endorsed by the Executive Board of the IMF in March 2004. The views expressed in this document are those of the FATF and do not necessarily reflect the views of the government of Norway or the Executive Board of the IMF. ROSCs do not rate countries' observance of standards and codes or make pass-fail judgments. Consequently, no overall assessment of the effectiveness of the anti-money laundering and combating the financing of terrorism regime is provided.

The policy of publication of staff reports and other documents by the IMF allows for the deletion of market-sensitive information.

To assist the IMF in evaluating the publication policy, reader comments are invited and may be sent by e-mail to publicationpolicy@imf.org.

Copies of this report are available to the public from

International Monetary Fund $\bullet$ Publication Services

700 19th Street, N.W. • Washington, D.C. 20431

Telephone: (202) $6237430 \bullet$ Telefax: (202) 6237201

E-mail: publications@imf.org • Internet: http://www.imf.org

Price: $\$ 15.00$ a copy

International Monetary Fund

Washington, D.C. 



\title{
$F A T F+G A F I$
}

Financial Action Task Force

Groupe d'action financière

\begin{abstract}
NORWAY
Report on Observance of Standards and Codes

FATF Recommendations for Anti-Money Laundering and Combating the Financing of Terrorism
\end{abstract}





\title{
REPORT ON OBSERVANCE OF STANDARDS AND CODES
}

\author{
FATF Recommendations for Anti-Money Laundering \\ and Combating the Financing of Terrorism
}

\author{
NORWAY
}

\section{BACKGROUND INFORMATION}

1. This Report on the Observance of Standards and Codes for the FATF 40 Recommendations for AntiMoney Laundering and 9 Special Recommendations Combating the Financing of Terrorism was prepared by the Financial Action Task Force. The report provides a summary of the AML/CFT measures in place in Norway, the level of compliance with the FATF 40+9 Recommendations, and contains recommendations on how the AML/CFT system could be strengthened. The views expressed in this document have been agreed by the FATF and Norway, but do not necessarily reflect the views of the Boards of the IMF or World Bank.

2. This report provides a summary ${ }^{1}$ of the AML/CFT measures in place in Norway as at the date of the on-site visit (January 2005) or immediately thereafter. It describes and analyses those measures, and provides recommendations on how certain aspects of the system could be strengthened. Recent AML/CFT priorities have been to increase the effectiveness of measures to detect, prosecute, and confiscate proceeds of crime; enhance international co-operation; competence building; comply with the current EU Money Laundering Directive; and train the 27 specialised economic crime units. In the last 10 years, Norway has seen an increase in profit-motivated crime (especially drug-related and economic crime). Serious crime in Norway has been characterised by the following general trends: better organisation and increased flexibility; increased internationalisation, specialisation and professionalism; increased co-operation between criminal networks and links with legal business activity, and more use of advanced technologies. Recent threat assessments conclude that organised crime and criminal networks are gaining more of a foothold and that money laundering continues to be characterised by extensive use of cash. A recent attempt to analyse possible connection between terrorist financing and organised crime does not provide basis for any definitive conclusions.

3. The following types of financial institutions are authorised to operate in Norway: savings banks, commercial banks, finance companies and mortgage companies; life and non-life insurance companies, emoney institutions, investment firms, security funds management companies and branches of foreign financial institutions. All are supervised by the Financial Supervisory Authority of Norway (Kredittilsynet) (the FSA). Foreign exchange offices (i.e. bureaux de change) and money/value transfer service (MVTS) providers are formally not permitted to operate in Norway as separate entities, though banks, finance companies and EEA branches of such undertakings are allowed to carry out such financial activities. The following types of non-financial businesses and professions operate in Norway: real estate agents, auditors and accountants (supervised by the FSA), lawyers (supervised by the Supervisory Council for Legal Practice (Supervisory Council), and dealers in precious metals and stones (not supervised for AML/CFT). Notaries do not exist in Norway. Casinos (including Internet casinos) are not allowed to operate in Norway, though Norwegians may gamble on Internet casinos that are operated from a server located in another country, and Norwegians may offer such a service in Norway from outside Norway. Trust and company services are normally provided by lawyers and auditors. Trust and company services providers are not recognised as separate businesses.

\section{LEgAL SYSTEM AND RELATED INSTITUTIONAL MEASURES}

4. Norway has criminalised money laundering under s.317 of the Penal Code. Charges can be brought for different types of money laundering, ranging in seriousness from drug-related money laundering to

\footnotetext{
${ }^{1}$ A copy of the full Mutual Evaluation Report can be found on the FATF website - www.fatf-gafi.org
} 
negligent money laundering. Overall, these offences are broad in scope and apply to all crimes. The offences have also been actively and successfully used, with the prosecuting authorities bringing 1693 cases since 2000, and achieving a high conviction rate (about $85 \%$ ), particularly considering that all convictions are for third party money laundering. Negligent money laundering is also criminalised. Some minor enhancements that could be made to an otherwise effective regime include extending the offence to self-laundering and conspiracy (which is currently only an offence if three or more people conspire in the context of an organised criminal group), increasing the use of more serious money laundering charges, and modifying the structuring/penalties of the different types of money laundering offences.

5. Terrorist financing is an autonomous offence under s.147b of the Penal Code, and covers obtaining or collecting funds or other assets with the intention that they are to be used to finance terrorist acts. This term "terrorist acts" refers to a range of existing criminal offences committed with certain specific intentions. Although Norway's criminalisation of terrorist financing is generally in line with the Terrorist Financing Convention, Norway should clarify its legislation to ensure that the offence covers collecting funds in the knowledge that they are to be used (for any purpose) by a terrorist organisation/individual terrorist. The offence is punishable by up to 10 years imprisonment. There has been one investigation but no prosecutions for terrorist financing in Norway.

6. In recent years, Norway has focused on measures that could enhance its ability to deprive criminals of the proceeds of crime, and the innovations adopted have been largely successful. The law provides for two types of provisional measures-charging and seizing (which in practice, operates like a freezing mechanism for certain types of assets, such as funds in a bank account) and these measures are sufficient in most cases. The police and the prosecution authorities have a full range of powers to identify and trace assets. Confiscation of the proceeds from any criminal offence or property of corresponding value is mandatory. Proof on the criminal standard that a specific criminal offence generated the proceeds is required; however, the burden of proof is eased to the civil standard concerning the amount of the proceeds which may be confiscated. Extended confiscation measures are also possible in serious cases, meaning there is a presumption that all of the defendant's property is illegally acquired. Proceeds or instrumentalities of crime can be confiscated from a third party in a range of circumstances. Overall, Norway has implemented a comprehensive confiscation system that is achieving results. In 2003, over 900 confiscation orders totalling over NOK 140 million (€17 million) were issued.

7. United Nations Security Council Resolution (UNSCR) S/RES/1267(1999) and its successor resolutions are implemented by an enabling statute and regulations. These laws provide some of the necessary measures by creating an authority to freeze, automatically incorporating any changes to the lists into the legal system, prohibiting anyone from making any funds available to entities listed, and providing for penalties of fines or imprisonment. Freezing can be legally challenged using normal legal mechanisms for challenging government decisions. Despite this, there is a lack of guidance to institutions and persons holding targeted assets, and no measures to monitor compliance. Norway has frozen one bank account under S/RES/1267(1999), and the effectiveness of the regime is noticeably reduced by the absence of further policies and procedures to handle freezing cases.

8. Norway has implemented S/RES/1373(2001) by enacting special provisions in its criminal procedure law, thus allowing property to be frozen when a person is suspected of terrorist offences. The decision to freeze is not based on a national list, but on a case-by-case assessment based on evidence (to the "more than $50 \%$ likely" standard) that the person has/has attempted to obtain/collect funds and assets in respect of the commission of terrorist acts or made funds available to terrorists/terrorist organisations. However, because the scope of the terrorist financing offence is not quite broad enough, Norway would be unable to freeze the assets of a person who is considered to have collected funds in the knowledge that they are to be used generally (for any purpose) by a terrorist organisation/individual terrorist. Moreover, there are no clear channels for communicating freezing actions taken under S/RES/1373(2001), no guidance to entities that may be holding assets covered by such a freezing action, and no system for monitoring compliance. With regards to S/RES/1373(2001), Norway has never found any funds/assets inside of Norway. Consequently, the freezing mechanisms that it has enacted in its criminal procedure law for this purpose has never been triggered. Overall, the freezing regime in Norway has implemented only some of the elements of Special Recommendation III. There is a lack of clear procedures for unfreezing and de-listing requests, authorising 
access to assets on humanitarian grounds, monitoring compliance and applying sanctions. An effective system for communication between government and the private sector needs to be established, and clear guidance provided to financial institutions.

9. Norway's financial intelligence unit, the Money Laundering Unit (MLU), is located within the National Authority for Investigation and Prosecution of Economic and Environmental Crime (ØKOKRIM) and has been a member of the Egmont Group since 1995. Suspicious transaction reporting in Norway takes place in two stages: (a) where a reporting entity suspects that a transaction is associated with the proceeds of crime, it must make further inquiries; (b) if those inquiries do not dispel the suspicion, then an STR has to be made to the MLU. The transaction can be temporarily frozen by the MLU: this power is exercised only a few times a year. In January 2005, the MLU had 11/2 employees, seven of which analysed STRs. This level of staffing is inadequate to deal with the volume of STRs that the MLU currently receives (more than 5000 in 2004). This is exacerbated by the MLU's manual processes such as an inability to receive STRs electronically and the lack of analytical software tools. An electronic reporting system and a new, improved STR database are due to be implemented. MLU staff have sufficient powers to obtain information from police, other government officials and foreign FIUs, can demand additional information from reporting entities, and has direct access to a wide range of databases. The MLU is subject to the oversight of the Control Committee; however, this oversight only extends to the protection of privacy and personal data. The Committee is an independent body that reports to the Ministry of Finance. While the Committee does not interfere with the MLU's independence; its intervention does impact the overall effectiveness of the MLU in that a disproportionate amount of the MLU's limited resources are now directed towards considering whether to delete or justify retaining old STR files. Information about an STR must be deleted if a suspicion is rebutted, or if after five years no investigation or legal measures have been initiated. Although, on paper, the MLU generally meets the literal requirements of Recommendation 26, its lack of effectiveness causes concerns and impedes the overall effectiveness of Norway's AML/CFT system. The MLU is understaffed, under-resourced and technologically ill-equipped, and though MLU staff are doing what they can given these limitations, the whole issue needs to be addressed. Norway should ring-fence the responsibilities and resources of the MLU.

10. The Norwegian police service is comprised of the Police Directorate, the Police Security Service (PST), the 27 police districts, and centralised institutions like ØKOKRIM, New Kripos and the Police College. They work closely with the Prosecution Authority. ØKOKRIM is responsible for investigating complex economic crime (including money laundering), while all police districts have established separate teams to combat economic crime. Money laundering offences and confiscation cases are investigated in every police district, and terrorist financing is investigated by the PST or by ØKOKRIM. Law enforcement has initiated 2342 money laundering investigations. Police and prosecutors have all the normal search and seizure powers, as well as powers to use special investigative techniques such as secret search and seizure, though some powers can only be used for more serious offences, thus limiting their availability for use in money laundering. Other covert measures, such as undercover operations are available, but are not statutorily regulated. Training is provided to police and prosecutors on economic crime, however, this should be expanded to meet the needs in the area.

\section{Preventive Measures - Financial InStitutions}

11. The current Norwegian AML legislation was adopted in June 2003, but does not yet take into account the full obligations set out in the revised FATF Recommendations (2003). Norway's customer identification measures are based on implementation of the $1^{\text {st }}$ and $2^{\text {nd }} E U$ Money Laundering Directives and the FATF Recommendations (1996). Norway reports that it has been waiting until the $3^{\text {rd }}$ EU Money Laundering Directive (which was just adopted) was finalised before doing so. There are no higher risk categories of customers or products, and the lower risk categories have been implemented in line with the EU Directives. The AML measures under the Money Laundering Act (MLA) and Regulations (MLR) apply to all the financial institutions that must be covered under the FATF Recommendations (referred to as "Reporting FIs" in Norway). 
12. Although Norway has implemented basic customer identification obligations, it has not implemented full customer due diligence (CDD) requirements. Reporting FIs are required to identify permanent and occasional customers (for large value transactions). A natural person's identity is normally verified by producing a document issued by a public authority, which normally contains full name, signature, photograph and personal identity number or D-number. (Non-residents liable to pay tax are registered with a unique D-number.) A legal person's identity is verified by checking certain Registers. Where the customer is unable to produce the required identity documents, the Reporting FI should generally refuse to establish a customer relationship. There are exemptions from the identification obligations if the customer is a Norwegian or EEA credit institution or investment firm, and for low value insurance contracts. ${ }^{2}$ Overall, there are weaknesses regarding the implementation of Recommendation 5, as the only measure currently in place is a bare requirement to identify customers. Elements going beyond the initial establishment of the customer relationship such as beneficial ownership and other elements of CDD are not required. These deficiencies need to be addressed. In addition, specific identification requirements and procedures should be introduced that are tailored to the business practices of sectors other than banking. Norway should also implement the applicable measures for politically exposed persons (PEPs) and correspondent banking (R.6 \& 7).

13. Normally, the establishment of non-face-to-face business relationships is not allowed and the customer must physically appear either at the Reporting FI or at an agent or outsourcee, where identification and verification is performed. Where there is outsourcing, the Reporting FI must ensure that the outsourcee conducts the customer identification and verification properly, maintains proper records, and properly trains its employees. Reporting FIs cannot rely on verification performed by another Reporting FI, even those that are part of the same financial group, and introductory business is generally not permitted. A legal duty of confidentiality requires employees of financial institutions to keep customer information confidential, but does not inhibit disclosure of information to the MLU, nor impede the FSA in performing its supervisory role. Indeed, banks, finance companies and insurance companies are allowed to exchange customer data when investigating suspicious transactions. It is recommended this authority be extended to other types of financial institutions. Record keeping requirements are generally satisfactory, with Reporting FIs being obligated to retain copies of any documents used to verify the customer's identity for five years after termination of the customer relationship, and to keep transaction records for ten years. The MLA requires relevant originator information to be kept for all permanent customers and the Currency Register Act and Regulations effectively extend this to occasional customers conducting any cross border wire transfer. However, in other respects, SR VII has not been implemented and this should be rectified.

14. Banks and finance companies were legally obliged to establish electronic monitoring systems before the end of 2004. Norway's initial experience with its new electronic monitoring system for banks and finance companies is a pattern of reporting that focuses more on the nature of the transaction, and not just the nationality of the customer and cash transactions. Monitoring of unusual transactions is conducted, the NCCT list is published and additional NCCT countermeasures applied. Reporting FIs are required to report transactions to the MLU when there is a suspicion that the transaction is related to money laundering or terrorist financing, and are exempt from liability when they report to the FIU in good faith. "Tipping off" a customer or any third party in connection with reporting a STR to the MLU is prohibited. Banks and MVTS providers report the largest number of STRs, though none of them were related to terrorist financing. It is a concern that the number of STRs being reported by other non-bank financial institutions is very small, and the number of STRs from banks is also decreasing.

15. Norway has recently revised its declaration system and also its systems for monitoring cross-border transportations of currency (cash). The declaration system is administered by the customs authorities and is regulated in the customs legislation. A new Currency Register Act provides for storing declaration information in a Currency Transaction Register. The Currency Transaction Register also monitors all cross-border transactions made through banks, the use of foreign credit cards in Norway, the use of Norwegian credit cards abroad, and the exchange of currency above NOK 5000 (USD 800) or the

\footnotetext{
${ }^{2}$ In the context of Recommendation 5, the Norwegian regime exempts their financial institutions from certain AML/CFT obligations in relation to financial institutions that are located in countries belonging to the European Economic Area. The FATF decided at the June 2005 Plenary to further consider this subject.
} 
equivalency in another currency. The police have direct access to the Register when a criminal investigation has been initiated. The declaration system applies to all incoming and outgoing cross-border transportations of currency equal to or exceeding NOK 25000 (€ 3000 ) or the equivalent value in a foreign currency. Name, date of birth, personal identification number or passport number, the amount/value transported and the date are recorded for all transactions. For amounts above NOK 100000 (€12 100), the purpose of the transportation is also registered. The legal measures are broadly adequate, and allow the police to stop smuggled money when it is detected, giving the police time to investigate the money in question. There is no obligation to declare bearer negotiable instruments when entering or leaving Norway. However, when foreign negotiable instruments are cashed, this is reported to the Currency Transaction Register. Norway indicates that the reason for this is that the transaction occurs when the instrument is cashed, and also avoids the double reporting of transactions in the Register.

16. All Reporting FIs must establish certain internal control and communications procedures, and appoint an AML officer. Reporting FIs must have an internal audit function and designate an AML/CFT compliance officer person within senior management. Special training programmes for employees and other relevant persons on AML/CFT obligations are required. While these measures are generally satisfactory regarding checking the existing laws, they do not implement the full range of measures required under the Recommendations and it appears that institutions have not voluntarily implemented higher standards. Foreign branches of Norwegian institutions are obligated to observe AML/CFT measures consistent with Norwegian requirements and the FATF Recommendations to the extent that the host country's laws permit. Norway has not yet had any cases of foreign subsidiaries of Norwegian institutions being established abroad in countries that are considered to have lesser AML/CFT measures than Norway. Norway should implement an obligation to inform the FSA if a foreign branch or subsidiary is unable to observe appropriate AML/CFT measures. Shell banks are indirectly prohibited in Norway. However, there are no provisions prohibiting financial institutions from entering correspondent banking relationships with shell banks or obligating institutions to satisfy themselves that their foreign respondent institutions do not permit their accounts to be used by shell banks. All these measures should be introduced as soon as possible.

17. The FSA is an independent government agency, responsible for supervising the Norwegian financial sector. The licensing function is divided between the Ministry of Finance and the FSA. When a financial institution is granted a licence, checks are conducted to ensure that the general manager and directors meet fit and proper requirements. This includes a criminal records check. Supervisory resources are allocated on a risk sensitive basis and the FSA looks to co-ordinate its prudential approach with its AML/CFT supervision. The FSA has adequate powers to supervise and inspect the policies, practices and internal controls of Reporting FIs. It is also authorised to impose a broad range of administrative sanctions for non-compliance, from letters requesting corrective action, orders through to fines or de-licensing. Sanctions can be applied against both institutions and officers/employees, though its powers to do the latter should be clarified. To date the FSA has imposed sanctions for breaches of AML/CFT obligations in the form of issuing letters requesting that corrective action be taken. At the end of 2003, the FSA had 183 employees responsible for supervising 2518 separate entities (including designated non-financial businesses and professions (DNFBPs) — except lawyers and dealers), 5338 auditors, 518 auditing firms, 6721 external accountants and 242 external accounting firms. Considering the number of entities that the FSA is responsible for supervising, this seems to be an inadequate number of staff. In the past six years, the FSA has conducted between 100-120 on-site inspections per year, in addition to off-site reviews. Although AML/CFT assessments are integral part of the FSA's regular visits, they seem to be limited in scope and not conducted frequently enough. For smaller financial institutions, AML/CFT assessments are not held annually, but only when there are indications that an assessment would be necessary. Only 12 thematic inspections focusing solely on AML issues have been conducted. The assessors found that some of these institutions (deemed to be high risk) had just been assessed for the first time in seven years, and the assessment found some major shortcomings. This situation needs to be reviewed. The FSA should consider how it can best enhance focus on AML/CFT issues, for example, by having a team of examiners that checks compliance with AML/CFT on an ongoing basis for all supervised entities.

18. Some steps have been taken concerning guidance. The FSA has issued Circular 9/2004 to reporting entities on how to comply with their obligations, while the MLU has also given some sporadic guidance 
and participates in seminars for the private sector. However, the guidance seems to have been insufficient, and reporting entities (both financial institutions and DNFBPs) met by the assessment team asked for additional and more sector-specific guidance (particularly in the area of typologies). Additionally, the MLU should enhance its general and specific feedback concerning the status of particular STRs and the outcome of certain specific cases.

19. Unauthorised MVTS providers are illegal, and Norway has detected some underground banking. Two cases have been successfully prosecuted. Regulated MVTS providers (banks and finance companies) are subject to the FATF Recommendations, albeit not adequately. This negatively impacts on the effectiveness of AML/CFT measures in the MVTS and other financial institution sectors. Norway should take steps to properly implement Recommendations 5-7, 15 and 22, and SR VII overall. The FSA is responsible for licensing and monitoring MVTS operators, however, there are concerns about the effectiveness of this supervision. The FSA is taking action to correct these problems.

\section{Preventive Measures - Designated Non-FinanCial Businesses AND Professions}

20. The following DNFBP are subject to AML/CFT obligations: real estate agents, dealers in objects, including precious metals/stones, in connection with cash transactions of NOK 40000 (€4 800) or more, lawyers and other independent legal professionals, auditors and accountants (collectively referred to as Reporting BPs). Land-based casinos, notaries and trust/company service providers (as a separate defined business sector) do not exist in Norway. Although the large majority of company services are handled by lawyers and accountants, there is no legal prohibition from other persons establishing such businesses in Norway. Norway should clarify the law to ensure that anyone providing such service is covered. This may include amending the law to restrict the provision of company services to only accountants and lawyers to reflect the current practice. For the most part, AML/CFT obligations for Reporting FIs/BPs are the same. Consequently, the same deficiencies in the implementation of customer identification requirements (Rec.5) exist. Customer identification requirements have been implemented, but full CDD requirements have not. Nor have any measures concerning PEPs (Rec.6) been implemented in the DNFBP sectors. Norway should correct these deficiencies as a matter of priority. All dealers in objects, including dealers in precious metals/stones, auctioneering firms, commission agents and the like, are obligated to identify their customers when carrying out cash transactions involving NOK 100000 (€12 100) or more, or suspicious transactions involving NOK 40000 ( $€ 4$ 800) or more. In the latter case, an STR must be filed with the MLU. However, overall it is unclear how effectively dealers in precious metals/stones are complying with AML/CFT requirements because they are not monitored or supervised in this regard. Norway should designate an authority responsible for doing so. Occasional customer rules do not apply to lawyers, independent legal professionals, real estate agents, accountants or auditors since, due to the nature of their work, they do not have occasional customers.

21. In general, Reporting BPs have satisfactorily implemented record keeping requirements. Although Reporting BP are not allowed to establish non-face-to-face business (customers must physically appear at the Reporting BP or its agent/outsourcee for identification and verification), there are some concerns about the effectiveness of this system in practice. All of the Reporting BP met with had established internal AML/CFT controls and communication routines as required. Reporting BP must monitor their accounts and report suspicious activity to the MLU. Lawyers are only obliged to report suspicious transactions when assisting or acting on behalf of clients in planning or carrying out financial transactions, with certain exceptions. So far, only lawyers, accountants, auditors and real estate agents have filed STRs; dealers in precious metals/stones have not. However, this obligation is quite new for most Reporting BPs. Nevertheless, there are preliminary concerns about effectiveness because most of the DNFBP sectors met with during the on-site visit (particularly real estate agents, accountants, auditors, and dealers in precious metals/stones) requested more sector-specific guidance (particularly typologies). Although the FSA has issued general AML/CFT guidelines to real estate agents, accountants and auditors (Circular 9/2004), more tailored and sector-specific guidance should be issued to the Reporting BPs as soon as possible to address these concerns. Currently, two working groups are set up in order to propose such guidelines for lawyers and auditors/accountants. The NARF (Norway's major professional body for authorised external accountants) is currently developing a quality control programme for external accountants. 
22. Real estate agents, accountants and auditors must be licensed by the FSA in order to be authorised to carry out their business. The FSA supervises these entities, issues guidance to them on an ad hoc basis and is empowered to apply administrative sanctions. However, the FSA does not appear to have sufficient resources to do so effectively. The FSA has not started inspecting accountants/auditors because the scope of their reporting obligation has not been fully clarified. The Supervisory Council licenses, supervises, audits and sanctions the legal professionals. The Supervisory Council conducts between 50-70 audits per year of law firms, including checks on AML/CFT compliance. The Supervisory Council has only uncovered one case of money laundering by a lawyer. The Norwegian Bar Association (NBA) has issued binding ethical guidelines for lawyers (which specifically refer to ML) and has compiled a template for internal controls and communication routines. It is also in the process of participating in a Ministry of Justice \& Police committee to draft AML/CFT guidelines for legal professionals. Dealers in precious metals/stones are obliged to register their activity or company, but do not need to be licensed or authorised to conduct business. This sector is not supervised or monitored by any agency for compliance with AML/CFT obligations, although industrial associations play a role in helping members to understand and apply new legal requirements, including those related to AML/CFT. The MLU has taken the initiative, passing on information about Norway's new AML/CFT legislation to industry organisations such as NHO and HSH. Nevertheless, without any supervision or monitoring, there is no way of assessing how effectively AML/CFT measures are being implemented in this sector. Norway should designate an authority to fulfil this role.

23. Although there are no land-based casinos in Norway, limited and closely regulated internet gaming does exist. Although having an ownership interest in an internet casino is not expressly prohibited, Norway reports that such activity could be stopped pursuant to existing gaming legislation. However, Norway has not taken any measures to identify whether any Norwegian residents/citizens currently own or operate an internet casino, a company that runs an internet casino or a server located in Norway which hosts an internet casino. Nor has any guidance been issued to Reporting FIs/BPs alerting them to the possible existence of such entities and how to treat them. Norway should be aware of issues relating to the illicit operation of internet casinos in Norway, and should be prepared to address these problems. ${ }^{3}$ Additionally, Norway's efforts to encourage the development and use of modern, secure techniques for conducting financial transactions that are less vulnerable to money laundering should continue.

\section{Legal Persons and Arrangements \& Non-Profit Organisations}

24. Norway has several registries for legal persons. All Norwegian legal persons, and Norwegian and foreign companies or other legal persons conducting business activities in Norway are obligated to register with one or more registers. Registered information concerning a particular legal person can be readily retrieved by virtue of Norway's single number identification system. Norway has also implemented measures to ensure that this information is updated. Additionally, Norway obligates all Norwegian private and public limited companies to establish and maintain a register of all shareholders that must be kept upto-date and must be made available to anyone who asks. Foreign companies are allowed to own shares of Norwegian companies and, in such cases, the register of shareholders will identify the foreign company. Norwegian authorities are entitled to ask the foreign company for that information. However, the information accessible will depend on home state requirements. These measures ensure that accurate, adequate and reasonably current information concerning the ownership and control of Norwegian legal persons is readily accessible to competent authorities in a timely fashion. However, it should be noted that these measures do not expressly relate to information concerning beneficial ownership (as that term is used in the FATF Recommendations). Nevertheless, Norway has implemented additional measures that go some way to ensuring that the person who exercises ultimate effective control over a legal person can be identified. First, listed public companies are subject to shareholder disclosure rules. Second, Norwegian law prohibits the buying/selling of shares through a nominee, except as regards foreign investors, and then

\footnotetext{
3 These observations have not affected Norway's rating on compliance with the FATF Recommendations (in particular, Recommendations 12, 16 or 24). The FATF decided at the June 2005 Plenary to study the issue of internet casinos to clarify AML/CFT obligations in relation to this activity.
} 
only with safeguards to ensure transparency. Third, bearer shares do not exist in Norway. Nevertheless, concerning beneficial ownership, additional steps could be taken to provide more timely access to this sort of information.

25. Charitable organisations are not obligated to register; however, their bank accounts must be opened in the name of a natural person who is a member. The FSA specifically advises Reporting FIs/BPs that collection accounts for charitable organisations should not be exempt from the requirements to produce identity documents. Nevertheless, this situation is unsatisfactory because it hinders the bank's ability to identify the actual owners of funds in an account and leaves the natural person (in whose name the account is registered) subject to tax on the funds concerned. The system is further weakened by the fact that Recommendation 5 has not been implemented with regards to beneficial ownership. Norway has not reviewed its laws/regulations relating to non-profit organisations (NPOs) as required by Special Recommendation VIII. Norway should do so, and implement appropriate CFT measures in this sector. Norwegian law does not recognise the legal concept of a trust or similar legal arrangements, including trusts created in other countries.

\section{NATIONAL AND INTERNATIONAL CO-OPERATION}

26. With a few exceptions, Norway has fully implemented the elements of the Vienna, Palermo and Terrorist Financing Conventions that are relevant to the FATF Recommendations. Norway has largely implemented the basic legal provisions of S/RES/1267(1999), but should implement measures to monitor or supervise for compliance with these requirements. Norway's implementation of S/RES/1373(2001) should be improved. On an operational level, the FSA is authorised to co-operate with other domestic supervisors, law enforcement authorities and foreign supervisors for AML/CFT purposes. Several informal mechanisms, including regular contact meetings and forums exist to improve interagency co-operation between the police, Prosecution Authority, MLU, customs and tax authorities and supervisors with regards to AML/CFT. There is still room for improvement in more effective interagency co-operation.

27. Mutual legal assistance and extradition measures apply equally to money laundering and terrorist financing matters. Norway can respond to both mutual legal assistance and extradition requests in the absence of an applicable treaty. Extradition to Nordic countries is regulated by the Nordic Extradition Act (NEA). Extradition to other countries is regulated by the Extradition Act (EA). Mutual legal assistance is regulated by a separate chapter of the EA. Norway is party to international agreements facilitating mutual legal assistance within the Nordic region, the EU and between Schengen countries. Mutual legal assistance requests from non-Nordic countries seeking coercive measures are subject to the requirement of dual criminality. Although in general, there are no legal or practical impediments to rendering assistance, provided that both Norway and the requesting country criminalise the conduct underlying the offence, the application of dual criminality may create obstacles to both mutual legal assistance and extradition where the underlying offence relates to the following types of money laundering/terrorist financing activity that have not been properly criminalised in Norway: (i) self-laundering; (ii) conspiracy of 2 people to commit money laundering; and (ii) obtaining or collecting funds/assets to be used by a terrorist organisation/individual terrorist (for any purpose) where those funds have not yet been provided to the terrorist organisation/individual terrorist . Norway should take measures to address this problem, in particular, by properly criminalising these activities. Requests from non-Nordic countries (other than Nordic and Schengen countries) must also meet some of the requirements for extradition. Neither dual criminality nor the requirement that the underlying offence be extraditable apply to mutual legal assistance requests from Nordic countries. Generally, mutual legal assistance requests are forwarded through the Ministry of Justice \& Police. Norway reports that requests are given priority; however, there are no statistics concerning the length of processing times for either mutual legal assistance or extradition requests. Procedures for processing mutual legal assistance requests from Nordic and Schengen countries (which, given Norway's geographical location, would usually account for the majority of requests) are streamlined and can be sent directly between judicial authorities. Mutual legal assistance requests from other countries must always proceed by letters rogatory (which is not efficient). Duties of confidentiality do not impede mutual legal assistance. Assistance can be provided even where the offence is considered to involve fiscal matters. A wide range of mutual legal assistance can be provided, including compelling witness testimony, order the production of documents and seizing evidence. Norway co-operates closely on a 
global and region level to avoid conflicts regarding investigation/prosecution of cases concerning transnational crime.

28. Where a foreign state (that is not a signatory to the Vienna or Strasbourg Conventions) requests Norway to execute a foreign freezing/seizing/confiscation order, Norway can only recognise the order, but cannot give effect to it without starting its own proceedings. A procedure that requires a case to be made out before a local (Norwegian) court on the basis of foreign evidence is inherently less effective than one where the Norwegian court satisfies itself that a foreign court has made a freezing/seizing/confiscation order, and then simply gives effect to that order. Norway should enhance the effectiveness of its system by enacting legislation that would clearly allow for confiscation in situations other than those covered by the Vienna and Strasbourg Conventions, and should consider enacting measures that would allow it to give effect to a foreign freezing/seizing/confiscation order without the necessity of starting its own domestic proceedings. Although, to the best of Norway's recollection, no such requests have been made, Norway recognises that this issue will have to be addressed as it goes forward and as requests for international co-operation increase. Although there are no special permanent arrangements for coordinating seizure/confiscation actions with other countries, Norway does co-ordinate on a case-to-case basis. No asset forfeiture fund exists.

29. Both money laundering and terrorist financing are extraditable offences. Norwegian nationals may not be extradited (except to Nordic countries). When extradition is refused on this basis, the case will be forwarded upon request to the Prosecution Authority for a determination of whether domestic proceedings should be initiated. Extradition must be refused if there is a grave danger that the person concerned will suffer persecution directed against his life/liberty for reasons of race, religion, nationality, political convictions or other political circumstances. Proceedings may be transferred in the absence of an international convention. Dual criminality is applied to extradition requests (except those to Nordic countries). Norway collects statistics (which are not always reliable) on the number of requests for mutual legal assistance, extradition, freezing/seizing/confiscation and requests from foreign FIUs. However, Norway should keep additional statistics, including those relating to the nature of mutual legal assistance/extradition requests, whether the request was granted/refused, and how much time was required to respond. Norwegian law enforcement authorities are authorised to conduct investigations on behalf of foreign counterparts. They also have well-functioning systems of electronically stored information that is easy to find and easy to forward to other countries. Information is exchanged with foreign counterparts on the condition that it only be used for professional purposes, and is not made subject to disproportionate or unduly restrictive conditions. Generally, the attitude of Norwegian law enforcement is to respond rapidly to requests from co-operating agencies abroad.

30. The MLU can exchange information with foreign FIUs (both police/prosecution-based FIUs and administrative FIUs), both spontaneously and upon request, without an MOU. The MLU has an MOU with the Belgian FIU and requests from nine other foreign FIUs are pending. Norway should finalise these MOU as soon as possible to avoid the negative impact created by a situation where the foreign FIU needs to have an MOU in order to be able to co-operate. When responding to requests from foreign counterparts, the MLU can use the information from its own database and others that it has access to (including law enforcement and public databases). However, last year, due to a technical failure, connectivity with the Egmont Secure Web System, the MLU was lost for about three months. The technical problem was resolved and the MLU has designated staff to deal with international requests; however, it is too early to assess how effective these new measures will be. Norway should ensure that these new systems are working effectively.

31. Norway is a party to a number of international agreements and participates in working groups that are targeted at facilitating co-operation within the EU in various sectors, including insurance and securities. Norway has negotiated MOUs with foreign supervisory authorities in the banking and investment sector. Norwegian supervisory authorities may co-operate spontaneously with foreign supervisory authorities, even in the absence of any applicable agreement or statutory provision provided that the execution of the request is not contrary to Norwegian law. For instance, the FSA has co-operated with its foreign counterparts in relation to on-site inspections of Nordic banking groups. As a general rule, 
the Customs Directorate co-operates with its foreign counterparts on the basis of MOUs. However, the Norwegian customs authorities also may exchange information with other countries according to the customs legislation. Information may be exchanged provided that information can be shared on a mutual basis and the recipient stores and protects the information properly.

\section{Recommended Action Plan to Improve the AML/CFT System}

\begin{tabular}{|c|c|}
\hline AML/CFT System & Recommended Action (listed in order of priority) \\
\hline \multicolumn{2}{|c|}{ 2. Legal System and Related Institutional Measures } \\
\hline $\begin{array}{l}\text { Criminalisation of Money } \\
\text { Laundering (R.1 \& 2) }\end{array}$ & $\begin{array}{l}\text { Criminalise conspiracy involving } 2 \text { people to commit ML. Extend the ML offence to self-laundering. } \\
\text { Ascertain why the number of aggravated } \mathrm{ML} \text { cases remains small (even though the threshold for the } \\
\text { offence is very low). Depending on the underlying reasons, Norway should consider whether additional } \\
\text { legislative or training measures need to be taken. }\end{array}$ \\
\hline $\begin{array}{l}\text { Criminalisation of } \\
\text { Terrorist Financing } \\
\text { (SR.II) }\end{array}$ & $\begin{array}{l}\text { Clarify the legislation to ensure that the offence covers collecting funds in the knowledge that they } \\
\text { are to be used (for any purpose) by a terrorist organisation/individual terrorist. }\end{array}$ \\
\hline $\begin{array}{l}\text { Confiscation, freezing } \\
\text { and seizing of proceeds } \\
\text { of crime (R.3) }\end{array}$ & $\begin{array}{l}\text { Norway should continue its work in improving the awareness of police concerning the need to secure } \\
\text { confiscation claims (either by charging or seizure) early on in the case. Norway should consider } \\
\text { implementing the following elements that, while not required by the FATF Recommendations, would } \\
\text { further enhance an already effective confiscation regime: giving the authorities the power to } \\
\text { seize/charge all of the defendant's property in appropriate cases (not just ensuring that the court can } \\
\text { order a defendant to disclose all of his/her assets and allowing property to be seized/charged after a } \\
\text { confiscation order has been issued. Norway should examine whether better data could be collected } \\
\text { to identify the reasons for failure to recover the some proceeds and whether it is changing over time. }\end{array}$ \\
\hline $\begin{array}{l}\text { Freezing of funds used } \\
\text { for terrorist financing } \\
\text { (SR.III) }\end{array}$ & $\begin{array}{l}\text { Amend the laws to fully implement S/RES/1373(2001) consistent with its aims and objectives, } \\
\text { preferably in a similar way as S/RES/1267(1999) has been implemented. This would create one } \\
\text { single system for designating, listing, freezing, de-listing and de-freezing of terrorist assets. Enact } \\
\text { measures that would allow for the possibility of freezing funds or other assets where the suspect } \\
\text { belongs to a terrorist organisation or is known to finance such organisations or terrorists in general } \\
\text { (even if the financing cannot be connected to an act of terrorism. In relation to S/RES/1373(2001): } \\
\text { (i) implement effective systems for ensuring that relevant information is guided through } \\
\text { government authorities to the financial community; (ii) improve implementation of } \\
\text { S/RES/1373(2001). Give clear practical guidance to financial institutions concerning how to } \\
\text { implement freezing actions under S/RES/1267(1999) or S/RES/1373(2001) and develop policy } \\
\text { and procedures to handle freezing cases. Have measures in place to monitor compliance with } \\
\text { both S/RES/1267(1999) and S/RES/1373(2001). In relation to S/RES/1267: establish an effective } \\
\text { system for communication among governmental institutions and with the private sector (and the } \\
\text { like) to facilitate every aspect of the freezing/unfreezing regime within Norway; provide clear } \\
\text { guidance (more than the bare reporting obligation in the MLA) to financial institutions that may } \\
\text { hold terrorist funds concerning their responsibilities under the freezing regime; create a procedure } \\
\text { for considering de-listing requests and for unfreezing the funds or other assets of de-listed } \\
\text { persons; create a procedure for unfreezing, in a timely manner, the funds/assets of persons } \\
\text { inadvertently affected by the freezing mechanism upon verification that the person is not a } \\
\text { designated person; .clarify the procedure for authorising access to funds/assets that are frozen } \\
\text { and that are determined to be necessary on humanitarian grounds in a manner consistent with } \\
\text { S/RES/1452(2002); and create an appropriate procedure for a judicial review of freezing actions. }\end{array}$ \\
\hline $\begin{array}{l}\text { The Financial Intelligence } \\
\text { Unit and its functions } \\
\text { (R.26, } 30 \text { \& 32) }\end{array}$ & $\begin{array}{l}\text { It is recommended that Norway allocate more staff and technological resources to the MLU as } \\
\text { soon as possible. In particular, the MLU needs better technology. Although the staff are very } \\
\text { professional and highly trained, all staff need to be trained in the use of analytical tools such as } \\
\text { Analysts Notebook. In addition to a system for electronic reporting, the MLU urgently needs tools } \\
\text { to conduct electronic analysis as soon as possible. The management and resources of the MLU } \\
\text { currently are not ring-fenced. It is recommended that Norway ring-fence the responsibility and } \\
\text { resources of the MLU. It is recommended that Norway should reconsider the twin rules of deleting } \\
\text { STR information not acted on within } 5 \text { years and STR information where the suspicion has been } \\
\text { rebutted. Norway should improve the MLU's statistics collection capabilities by providing it with } \\
\text { better technological tools. The Police Directorate is planning for a new national intelligence system } \\
\text { which makes it possible to search for information in all the police databases from one platform to } \\
\text { gather all information in one database in order to co-ordinate and facilitate searches for } \\
\text { information. There is now a discussion at the Police Directorate to link and match this register with }\end{array}$ \\
\hline
\end{tabular}




\begin{tabular}{|c|c|}
\hline & $\begin{array}{l}\text { the information from STRs. Norway should ensure that this initiative does not negatively impact } \\
\text { the MLU's ability to securely protect and disseminate STR information only in accordance with the } \\
\text { law. }\end{array}$ \\
\hline $\begin{array}{l}\text { Law enforcement, } \\
\text { prosecution and other } \\
\text { competent authorities } \\
\text { (R.27, 28, } 30 \text { \& 32) }\end{array}$ & $\begin{array}{l}\text { Norway should ensure that sufficient priority is given to AML efforts with regards to the Police } \\
\text { College's involvement, ØKOKRIM and others. Likewise, even though the Action Plan } 2004 \\
\text { recognises that more resources need to be allocated towards training, and the Police College had } \\
\text { hired a staff member specifically for that purpose, the hire was cancelled just prior to the on-site } \\
\text { visit. Norway should ensure that this hiring is carried out as soon as possible. Norway should } \\
\text { ensure that additional resources are allocated to AML/CFT training for police and prosecutors. } \\
\text { Norway should collect statistics concerning the types of criminal sanctions imposed for ML. }\end{array}$ \\
\hline \multicolumn{2}{|c|}{ 3. Preventive Measures - Financial Institutions } \\
\hline $\begin{array}{l}\text { Customer due diligence, } \\
\text { including enhanced or } \\
\text { reduced measures (R.5 to } \\
\text { 8) }\end{array}$ & $\begin{array}{l}\text { Norway should implement the following missing elements of Recommendation } 5 \text { as a matter of } \\
\text { priority: there should not be an exemption from customer due diligence if the reporting Fl has actual } \\
\text { suspicion that a transaction is connected with ML/TF (i.e. there should not be an exemption from } \\
\text { MLA section } 5 \text { para.3); there is no requirement for a Reporting FI to re-perform customer } \\
\text { identification when it has doubts about previously obtained identification data. Presently the } \\
\text { obligation is only to verify data if the information contained in the presented documents is on its face } \\
\text { incorrect (MLR s. 8); although there are extensive requirements for identification of a customer that } \\
\text { is a legal person, there is no requirement for a Reporting FI to verify that an individual purporting to } \\
\text { act on behalf of that legal person is in fact so authorised; there is no definitive duty imposed on a } \\
\text { Reporting FI to check if the customer is acting on behalf of another person. Currently the duty is a } \\
\text { contingent one (i.e. to check only if it has reasons to suspect this to be the case); there is also no } \\
\text { duty imposed to check the corporate or ownership structure behind a customer who is a legal } \\
\text { person, by identifying, for example, the controlling shareholder or operating mind behind the } \\
\text { customer; there is no duty imposed to inquire as to the purpose and intended nature of the business } \\
\text { relationship vis-à-vis the Reporting Fl itself; reporting Fls are not required by law to conduct ongoing } \\
\text { due diligence on their business relationships; and there are also no rules governing the CDD } \\
\text { treatment of existing customers. Norway should implement both Recommendations } 6 \text { and } 7 \text { as a } \\
\text { matter of priority. Norway is recommended to reassess the existing identification requirements and } \\
\text { procedures and consider developing measures that are more tailored to the business practices of } \\
\text { the non-bank financial sectors. }\end{array}$ \\
\hline $\begin{array}{l}\text { Financial institution } \\
\text { secrecy or confidentiality } \\
\text { (R.4) }\end{array}$ & $\begin{array}{l}\text { Allowing a confidentiality override so that banks can exchange information in the course of } \\
\text { investigating suspicious transactions is sensible, but Norway should consider extending this to } \\
\text { other types of Reporting Fls. This recommendation does however not affect the rating }\end{array}$ \\
\hline $\begin{array}{l}\text { Record keeping and wire } \\
\text { transfer rules (R.10 \& } \\
\text { SR.VII) }\end{array}$ & $\begin{array}{l}\text { SR VII has not been implemented in most respects. Norway should implement the provisions of } \\
\text { SR VII as soon as possible. }\end{array}$ \\
\hline $\begin{array}{l}\text { Suspicious transaction } \\
\text { reports and other reporting } \\
\text { (R.13-14, 25 \& SR.IV) }\end{array}$ & $\begin{array}{l}\text { The FSA should ensure that non-bank financial institutions, including MVTS providers, comply } \\
\text { with their reporting obligations. Steps should also be taken to refocus reporting in general to } \\
\text { concentrate more on the nature of the transaction. The guidance given by the FSA should be } \\
\text { deepened, broadened and based on the different typologies, trends and techniques that focus } \\
\text { more attention on the nature of transactions themselves. Additional guidelines that are more } \\
\text { tailored to particular types of financial institutions should be issued. More outreach to the DNFBP } \\
\text { sectors should be undertaken to ensure that sector participants understand the rationale for the } \\
\text { reporting obligation and how to comply with it. The MLU should deliver more specific feedback to } \\
\text { reporting entities, particularly concerning the status of STRs and the outcome of specific cases. }\end{array}$ \\
\hline $\begin{array}{l}\text { Other types of reporting } \\
\text { (R.19 and SR IX) }\end{array}$ & $\begin{array}{l}\text { Overall, Norway's declaration system is insufficient in scope, and should be extended to include } \\
\text { incoming and outgoing cross-border transportations of bearer negotiable instruments. At a } \\
\text { minimum, the MLU, and possibly also the police/ØKOKRIM should have electronic access to the } \\
\text { Currency Transaction Register even where no investigation has formally commenced. The MLU } \\
\text { should be able to conduct a check against this register in the same way as it conducts checks } \\
\text { against many other registers when it receives an STR. In addition to distributing the lists of } \\
\text { persons designated under S/RES/1267(1999) to the customs authorities, lists of persons } \\
\text { designated under S/RES/1373(2001) should also be distributed. }\end{array}$ \\
\hline $\begin{array}{l}\text { Internal controls, } \\
\text { compliance, audit and } \\
\text { foreign branches (R.15 \& } \\
\text { 22) }\end{array}$ & $\begin{array}{l}\text { Reporting Fis should be obligated to establish screening procedures to ensure high standards } \\
\text { when hiring employees. Norway should implement a requirement that a financial institution } \\
\text { inform the FSA if its foreign branch or subsidiary is unable to observe appropriate AML/CFT } \\
\text { measures because this is prohibited by the laws or regulations of the host country. Once Norway } \\
\text { has corrected the legal requirements in the other areas of its AML/CFT regime (particularly with }\end{array}$ \\
\hline
\end{tabular}




\begin{tabular}{|c|c|}
\hline & $\begin{array}{l}\text { regards to customer identification measures), Reporting Fls should be obligated to implement } \\
\text { satisfactory internal controls in that regard. }\end{array}$ \\
\hline Shell banks (R.18) & $\begin{array}{l}\text { Norway should implement provisions that: (i) prohibit financial institutions from entering into or } \\
\text { continuing correspondent banking relationships with shell banks; and (ii) obligate financial } \\
\text { institutions to satisfy themselves that the respondent financial institution in a foreign country does } \\
\text { not permit its accounts to be used by shell banks. }\end{array}$ \\
\hline $\begin{array}{l}\text { The supervisory and } \\
\text { oversight system - } \\
\text { competent authorities and } \\
\text { SROs } \\
\text { (R. } 17,23,29 \& 30 \text { ). }\end{array}$ & $\begin{array}{l}\text { Although the FSA can sanction the officers/employees of the entities it supervises for failing to comply } \\
\text { with the MLA through its powers under the Financial Supervision Act, Norway should clarify the MLA in } \\
\text { this regard. The FSA should be given additional resources to be allocated for AML/CFT supervision. } \\
\text { The FSA should consider creating a well staffed stand alone AML/CFT unit or at least a team of } \\
\text { examiners specialising in AML/CFT measures that check Fls compliance with AML/CFT on an } \\
\text { ongoing basis for all supervised entities. }\end{array}$ \\
\hline $\begin{array}{l}\text { Financial institutions - } \\
\text { market entry and } \\
\text { ownership/control (R.23) }\end{array}$ & Financial institutions should be obligated to notify the FSA of changes in management. \\
\hline $\begin{array}{l}\text { AML/CFT Guidelines } \\
\text { (R.25) }\end{array}$ & $\begin{array}{l}\text { The FSA should respond to the requests of Reporting FIs/BPs for additional and more specific } \\
\text { AML/CFT guidelines on a more regular basis. Just as was done in the banking, insurance and } \\
\text { securities sectors, such guidance should be more tailored to the different types of Fls and DNFBPs. } \\
\text { The group that was established by the Ministry of Justice \& Police to propose AML/CFT guidance for } \\
\text { lawyers is encouraged to complete the final stages of its work as soon as possible. The NIPA, the } \\
\text { NARF and ØKOKRIM should finish developing guidance for accountants and auditors concerning } \\
\text { compliance with AML/CFT obligations. }\end{array}$ \\
\hline $\begin{array}{l}\text { Ongoing supervision and } \\
\text { monitoring (R.23, } 29 \text { \& 32) }\end{array}$ & $\begin{array}{l}\text { The self-assessment reports used to identify priority Fls for inspection visits should be revised to } \\
\text { include questions relating to AML/CFT. Norway should ensure that AML/CFT assessments of } \\
\text { Reporting Fls occur more regularly, particularly in high risk institutions. Norway should collect } \\
\text { and maintain statistics concerning the number and type of sanctions applied. }\end{array}$ \\
\hline $\begin{array}{l}\text { Money value transfer } \\
\text { services (SR.VI) }\end{array}$ & $\begin{array}{l}\text { The FSA should take immediate steps (including the application of sanctions, if necessary) to } \\
\text { correct the problems with reporting in this sector. The FSA should improve the effectiveness of } \\
\text { its monitoring and supervision of this sector. Norway should take steps to properly implement } \\
\text { Recommendations } 5-7,15 \text { and } 22 \text {, and SR VII. These measures should apply to all Reporting } \\
\text { FIs, including MVTS operators }\end{array}$ \\
\hline
\end{tabular}

\section{Preventive Measures -Non-Financial Businesses and Professions}

Customer due diligence and record-keeping (R.12)

Monitoring of transactions and relationships (R.12 \& 16)

Regulation, supervision and monitoring (R.17, 2425)

Other designated nonfinancial businesses and professions (R.20)
Norway should implement Recommendations 5 and 6 fully and make these measures applicable to both Reporting Fls/BPs. Overall, it should be made clear that any person who provides company services is subject to the MLA. Clarifying the rules could include codifying the current practice by amending the law to restrict the provision of company services to only certain groups (e.g. accountants and lawyers) to reflect the current practice.

Supervisors in the DNFBP sectors should issue detailed and sector-specific guidance as soon as possible concerning what sorts of transactions could be considered unusual and related to $\mathrm{ML} / \mathrm{FT}$. It would be preferable that lawyers be appropriately restricted or guided concerning what to advise a potential client when refusing to establish a customer relationship because it would imply an obligation to file a report to the MLU. In such circumstances, it should be sufficient to advise the potential client that the case cannot be accepted because of it would place the lawyer in a conflict of interest, rather than specifying that it would be the obligation to report to the FIU. However, this recommendation does not affect the rating.

An authority should be designated to monitor and supervise dealers in precious metals/stones for compliance with AML/CFT obligations. Norway should be aware of issues relating to the illicit operation of internet casinos in Norway, and should be prepared to address these problems. The FSA should be given more resources for the purpose of supervising and monitoring. The FSA should issue more tailored and sector-specific guidance to DNFBPs concerning how to properly implement their AML/CFT obligations.

Norway should continue to take measures to encourage the development and use of modern and secure techniques for conducting financial transactions that are less vulnerable to money laundering.

\section{Legal Persons and Arrangements \& Non-Profit Organisations}

Legal Persons - Access to beneficial ownership and control information (R.33)
Norway should take additional measures to ensure that information concerning beneficial ownership is available on a more timely basis. 


\begin{tabular}{|l|l|}
\hline $\begin{array}{l}\text { Non-profit organisations } \\
\text { (SR.VIII) }\end{array}$ & $\begin{array}{l}\text { Norway should conduct a review of the adequacy of its laws and regulations relating to non-profit } \\
\text { organisations that can be abused for the financing of terrorism. Norway should implement } \\
\text { measures to ensure that terrorist organisations cannot pose as legitimate non-profit }\end{array}$ \\
organisations. Norway should implement measures to ensure that funds or other assets collected \\
by or transferred through non-profit organisations are not diverted to support the activities of \\
terrorists or terrorist organisations.
\end{tabular}

\section{National and International Co-operation}

\begin{tabular}{|c|c|}
\hline $\begin{array}{l}\text { National co-operation } \\
\text { and coordination (R.31) }\end{array}$ & $\begin{array}{l}\text { Norway should take steps to improve co-ordination, particularly at the operational level. In the case } \\
\text { of the MLU, Norway should take steps to improve their co-ordination concerning the allocation of } \\
\text { budget and human resources by ring-fencing its budget. Norway should ensure that sufficient } \\
\text { resources are allocated to implement the recommendations in the Action Plan } 2004 \text {. }\end{array}$ \\
\hline $\begin{array}{l}\text { The Conventions and } \\
\text { UN Special Resolutions } \\
\text { (R.35 \& SR.I) }\end{array}$ & $\begin{array}{l}\text { Norway should fully implement: article } 6(2)(e) \text { of the Palermo Convention by making self-laundering } \\
\text { a criminal offence; article } 18(1)(\text { b) of the Terrorist Financing Convention by implementing effective } \\
\text { measures to identify beneficial owners; article } 18(1)(\mathrm{b}) \text { of the Terrorist Financing Convention by } \\
\text { implementing effective measures to identify beneficial owners; section } 8 \text { of S/RES/1267(1999) by } \\
\text { implementing measures to supervise and monitor reporting entities for compliance with freezing } \\
\text { orders issued pursuant to this resolution; and S/RES/1373(2001). }\end{array}$ \\
\hline $\begin{array}{l}\text { Mutual Legal } \\
\text { Assistance (R.32, 36- } \\
\text { 38, SR.V) }\end{array}$ & $\begin{array}{l}\text { At present, Norway has to rely on section } 24 \text { of the Extradition Act as the main provision under } \\
\text { which it provides mutual legal assistance. Norway should take measures to address the difficulties } \\
\text { that this creates (particularly with regards to the application of dual criminality to mutual legal } \\
\text { assistance requests from Nordic countries relating to ML/FT activities that have not been properly } \\
\text { criminalized in Norway). One way to do this would be to enact separate and comprehensive mutual } \\
\text { legal assistance legislation. Norway should consider applying even less restrictive requirements to } \\
\text { mutual legal assistance requests, particularly with regards to its application of dual criminality. In } \\
\text { particular, Norway should take measures to address the potential obstacles that dual criminality } \\
\text { presents in mutual legal assistance cases where the ML/FT activity has not been properly } \\
\text { criminalised in Norway. In particular, Norway should properly criminalise the following types of } \\
\text { ML/FT activities: (i) self-laundering; (ii) a conspiracy between } 2 \text { people to commit ML; and (ii) } \\
\text { obtaining or collecting funds/asset where the funds/assets are collected to be used by a terrorist } \\
\text { organisation or individual terrorist (for any purpose) - without, however, being made available to the } \\
\text { organisation or terrorist in question. Norway should keep a fuller set of statistics, thus enabling it to } \\
\text { better track the mutual legal assistance requests it receives and makes, and ensuring they are } \\
\text { handled in a timely way. Norway should consider enacting legislation that would clearly allow for } \\
\text { confiscation in situations other than those covered by the Vienna and Strasbourg Conventions. } \\
\text { Norway should also consider enacting measures that would allow it to give effect to a foreign } \\
\text { freezing, seizing or confiscation order, again in situations other than those covered by the Vienna } \\
\text { and Strasbourg Conventions, without the necessity of starting its own domestic proceedings. } \\
\text { Norway should keep statistics concerning: (i) the nature of mutual legal assistance requests; (ii) } \\
\text { whether the mutual legal assistance request was granted or refused; (iii) what crime the request } \\
\text { was related to; and (iv) how much time was required to respond to the request. }\end{array}$ \\
\hline $\begin{array}{l}\text { Extradition (R.32, } 37 \text { \& } \\
39, \& \text { SR.V) }\end{array}$ & $\begin{array}{l}\text { Norway should also ensure that the application of dual criminality does not impede extradition when } \\
\text { the case involves ML/FT activities that are not properly criminalised in Norway. In that regard, Norway } \\
\text { should properly criminalise: (i) self-laundering; (ii) conspiring to commit ML outside of the context of an } \\
\text { organised criminal group; and (iii) obtaining or collecting of funds/asset where the funds/assets are } \\
\text { collected to be used by a terrorist organisation or individual terrorist - without, however, being made } \\
\text { available to the organisation or terrorist in question - and where the use/intended use cannot be } \\
\text { connected with any form of terrorist act included in the scope of s.147a. Norway should also collect } \\
\text { and maintain statistics on: (i) the number of requests for extradition; (ii) the nature of the request; (iii) } \\
\text { whether the request was granted or refused; (iv) what crime the request was related to; or (v) how } \\
\text { much time was required to respond. Statistics concerning requests for extradition between the Nordic } \\
\text { countries that are sent directly to the prosecuting authorities should also be collected and maintained. }\end{array}$ \\
\hline $\begin{array}{l}\text { Other Forms of Co- } \\
\text { operation (R.32 \& } 40, \& \\
\text { SR.V) }\end{array}$ & $\begin{array}{l}\text { Norway should ensure that the MLU's new systems for facilitating co-operation with foreign } \\
\text { counterparts are working effectively. As well, Norway should collect and maintain statistics concerning } \\
\text { the number of sanctions applied, and the number of formal requests for assistance made and received } \\
\text { by supervisors relating to or including AML/CFT. Norway should also improve the certainty of its } \\
\text { statistics concerning the number of formal requests for assistance made to or received by the MLU } \\
\text { from foreign counterparts. }\end{array}$ \\
\hline
\end{tabular}

